\title{
STRATEGI PEMASARAN PRODUK OLAHAN DAGING BABI PRODUKSI MASYARAKAT DI DESA SEMAON KECAMATAN PAYANGAN KABUPATEN GIANYAR
}

\author{
Sumardani, N. L. G. ${ }^{1}$, T. I. Putri ${ }^{2}$, K. Budaarsa ${ }^{3}$, dan A. W. Puger ${ }^{4}$
}

\begin{abstract}
ABSTRAK
Pengembangan agribisnis tidak akan efektif dan efisien apabila hanya mengembangkan salah satu subsistem saja. Usaha peternakan akan lebih menguntungkan apabila peternak mampu mengolah langsung babi yang dipeliharanya menjadi produk yang memiliki nilai ekonomis lebih tinggi, misalnya: babi guling (suckling pig), nugget babi, urutan (sosis) babi, iga dan steak babi, serta produk olahan babi lainnya. Disamping itu juga diperlukan strategi yang tepat dalam memasarkan produk olahan daging babi yang telah diproduksi oleh masyarakat di Desa Semaon, Kecamatan Payangan, Kabupaten Gianyar. Pada tahun sebelumnya (2018) telah dilaksanakan penganekaragaman produk olahan daging babi, dan tahun ini (2019) dilaksanakan strategi pemasaran produk tersebut. Dengan demikian diharapkan nantinya dapat meningkatkan kesejahteraan masyarakat setempat melalui peningkatan pendapatan dari beternak babi dan mengolah daging babi, serta dapat menambah khasanah produk oleh-oleh khas Pulau Bali.
\end{abstract}

Kata kunci: penganekaragaman produk olahan, daging babi, strategi pemasaran, Desa Semaon Payangan, oleh-oleh khas Bali

\begin{abstract}
Agribusiness development will not be effective and efficient if it only develops one subsystem. Livestock business will be more profitable if the farmer is able to process directly the pigs that he raises into products that have higher economic value, for example: suckling pig, pork nuggets, pork sausages, ribs and pork steak, and other processed pork products. Besides that, an appropriate strategy is also needed in marketing processed pork products that have been produced by the community in Semaon Village, Payangan District, Gianyar Regency. In the previous year (2018) a diversification of processed pork products was carried out, and this year (2019) the product marketing strategy was implemented. Thus it is expected that later it will be able to improve the welfare of the local community through increasing income from raising pigs and processing pork, and can add repertoire of souvenir products typical of the island of Bali.
\end{abstract}

Keywords: diversification of processed products, pork, marketing strategies, Payangan Semaon Village, Balinese souvenirs

\section{PENDAHULUAN}

\footnotetext{
${ }^{1}$ Fakultas Peternakan Universitas Udayana; nlg_sumardani@unud.ac.id.

${ }^{2}$ Staf Pengajar Fakultas Peternakan Universitas Udayan; tjokputri0807@unud.ac.id

${ }^{3}$ Staf Pengajar Fakultas Peternakan Universitas Udayan; bdr.komang@unud.ac.id

${ }^{4}$ Staf Pengajar Fakultas Peternakan Universitas Udayan; puger.anton@unud.ac.id
} 
Desa Semaon merupakan salah satu desa di Kecamatan Payangan, Kabupaten Gianyar, Provinsi Bali yang dijadikan sentra peternakan babi ras untuk wilayah Gianyar Utara. Hal ini disebabkan karena kondisi lingkungan masyarakat dan iklim di desa tersebut sangat mendukung bagi usaha peternakan babi, baik dalam skala kecil, menengah, maupun dalam skala besar. Selama ini, peternak disini hanya sebagai pemelihara yang memelihara babi kemudian dipanen pada berat $\pm 100 \mathrm{~kg}$ dan dijual dalam kondisi hidup kepada tukang potong. Posisi peternak tidak sekuat posisi pasar, karena seringkali harga dimonopoli oleh pedangang besar, dan sering juga muncul permasalahan pada saat stok daging tidak habis terjual.

Menurut Sa'id (2001) sistem agribisnis terdiri dari beberapa subsistem yaitu: pengadaan dan penyaluran sarana produksi, kegiatan produksi primer (budidaya), pengolahan (agroindustri) dan pemasaran. Pengembangan agribisnis tidak akan efektif dan efisien apabila hanya mengembangkan salah satu subsistem saja. Peternak babi di Desa Semaon akan lebih menguntungkan apabila peternak mampu mengolah langsung babi yang dipeliharanya menjadi produk yang memiliki nilai ekonomis lebih tinggi, misalnya babi guling, nugget babi, sosis (urutan) babi (Budaarsa, 2012); Sumardani et al. (2019). Disamping itu juga diperlukan strategi yang tepat dalam memasarkan produk olahan daging babi yang telah diproduksi oleh masyarakat di Desa Semaon, Kecamatan Payangan, Kabupaten Gianyar.

Pada tahun sebelumnya (2018) telah dilaksanakan penganekaragaman produk olahan daging babi, dan tahun ini (2019) dilaksanakan strategi pemasaran produk tersebut. Dengan demikian diharapkan nantinya dapat meningkatkan kesejahteraan masyarakat setempat melalui peningkatan pendapatan dari beternak babi dan mengolah daging babi, serta dapat menambah khasanah produk oleh-oleh khas Pulau Bali.

\section{METODE PEMECAHAN MASALAH}

Kegiatan pengabdian masyarakat mengenai strategi pemasaran produk olahan daging babi produksi masyarakat di Desa Semaon, Kecamatan Payangan dilaksanakan melalui metode penyuluhan dan diskusi serta pemberian contoh-contoh produk olahan daging babi yang telah siap untuk dipasarkan. Penyuluhan dan diskusi membahas memengenai usaha peternakan babi dan cara mengolah daging babi menjadi aneka produk olahan yang bernilai ekonomi lebih tinggi. seperti: babi guling, nugget babi, urutan (sosis) babi, iga dan steak babi. Metode pelaksanaan kegiatan pengabdian juga didukung dengan pembuatan contoh-contoh kemasan produk olahan daging babi yang bisa dijadikan acuan dalam pengembangan usaha peternakan. Sasaran yang dilibatkan dalam kegiatan ini adalah peternak babi, pemilik rumah potong hewan (RPH) khusus babi, para pedagang daging babi, Dinas Peternakan dan masyarakat umum yang berminat dalam industri usaha peternakan babi.

\section{HASIL DAN PEMBAHASAN}

Kegiatan ini diawali dengan observasi dan sosialisasi serta pendekatan dengan ketua/kepala desa setempat, dan tokoh-tokoh yang disegani pada tanggal 9 Mei 2019 untuk membahas rencana pelaksanaan kegiatan pengabdian masyarakat, yang dilaksanakan sesuai dengan waktu dan kondisi masyarakat setempat di Desa Semaon Payangan Gianyar. Dari hasil diskusi tersebut, serta dari hasil diskusi dengan tim pelaksana dari Fakultas Peternakan Universitas Udayana, disepakati bahwa kegiatan pengabdian ini dilaksanakan pada tanggal 8 Juni 2019. Selama rentang waktu tersebut, tim pelaksana memepersiapkan segala sesuatunya, serta perlengkapan penunjang lainnya. Narasumber yang diundang dalam kegiatan ini adalah dosen Fakultas Peternakan Universitas Udayana yang memiliki keahlian dalam strategi pemasaran produk olahan daging babi, yaitu I Wayan Sukanata, S.Pt., M.Si yang menyampaikan tentang manajemen peternakan babi dalam usaha meningkatkan produksi ternak babi, dan narasumber Ni Luh Gde Sumardani, S.Pt., M.Si dengan materi tentang strategi pemasaran produk olahan daging babi. Bertindak sebagai moderator adalah Ir. Anthonius Wayan Puger, MS. Adapun peserta yang hadir sejumlah 60 orang, yang sangat antusias mengikuti acara ini sampai selesai (Gambar 1-2). Evaluasi kegiatan dilakukan setelah 
pelaksanaan kegiatan, terutama terhadap ide-ide kreatif dalam memasarkan produk olahan daging babi.
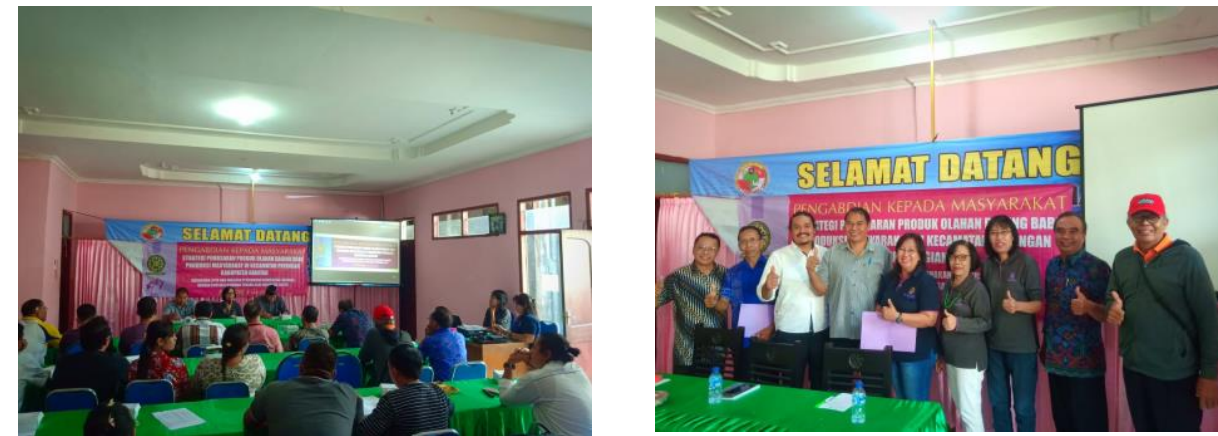

Gambar 1-2. Dokumentasi kegiatan bersama para narasumber dan moderator

Adapun salah satu produk olahan daging babi yang sudah siap dipasarkan hasil produksi masyarakat di desa ini adalah "urutan" daging babi (Gambar 3-5). "Urutan" daging babi ini merupakan olahan daging babi yang diolah sedemikian rupa dengan bumbu-bumbu tradisional bali dan dikemas menyerupai sosis. "Urutan" daging babi yang dikemas ini adalah "urutan" daging babi yang pengolahan ataupun pematangannya dengan cara di asap selama 24 jam.
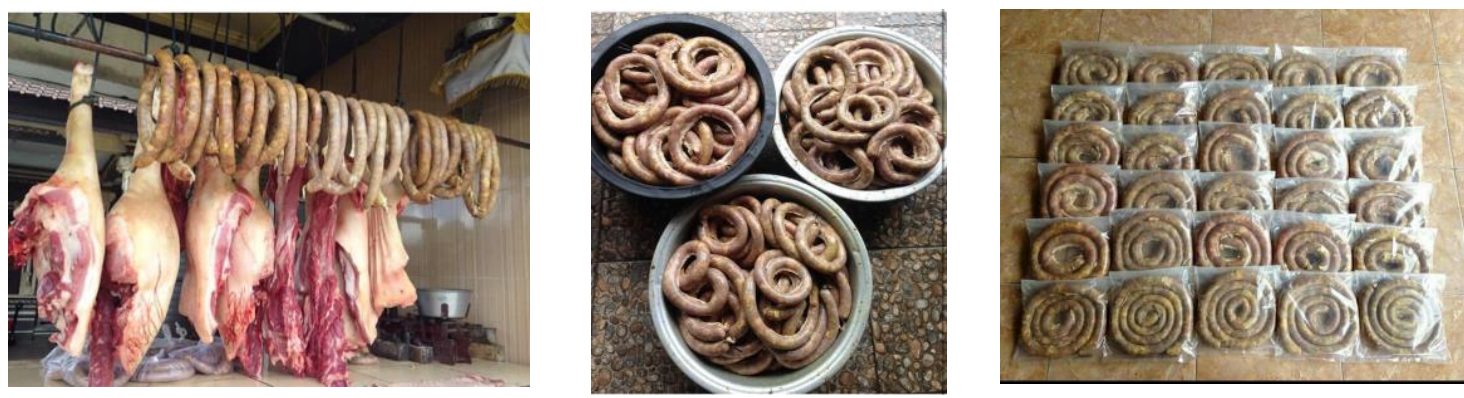

Gambar 3-5. Bahan daging babi sampai menjadi "urutan" daging babi

"Urutan" atau sosis daging babi adalah makanan khas Bali yang memiliki nilai gizi, lezat dan dengan cara pembuatannya yang unik. Dengan cara pengolahan yang sederhana dan pangsa pasar yang cukup besar, diharapkan "urutan" daging babi ini dapat dimanfaatkan sebagai industri rumah tangga, khususnya di Kecamatan Payangan, Kabupaten Gianyar. Produk ini dilihat dari strategi pemasaran adalah sangat berpotensi untuk dikembangkan di wilayah Payangan mengingat jalur lintas Payangan adalah jalur lintas pariwisata yang menghubungkan wilayah Gianyar dengan Kintamani, Bangli. Jika produk "urutan" daging babi ini diolah sedemikian rupa dan dikemas dengan baik, akan sangat menjanjikan sebagai oleh-oleh khas dari Payangan. Disamping itu juga, dengan adanya usaha ini merupakan kegiatan tambahan bagi ibu-ibu rumah tangga, dengan modal/biaya satu buah "urutan" daging babi yang sudah jadi Rp. 70.000,- dapat dijual dengan harga Rp. 150.000,- sampai Rp. 200.000,-- per kg dengan kemasan yang menarik dan praktis.

\section{SIMPULAN}

Dari hasil kegiatan diatas dapat disimpulkan bahwa pengembangan agribisnis tidak akan efektif dan efisien apabila hanya mengembangkan salah satu subsistem saja. Usaha peternakan 
akan lebih menguntungkan apabila peternak mampu mengolah langsung babi yang dipeliharanya menjadi produk yang memiliki nilai ekonomis lebih tinggi, dan memiliki strategi dalam memasarkan produk olahan yang dihasilkan, seperti produk olahan "urutan" daging babi yang dikemas secara menarik dan praktis.

\section{SARAN}

Program Udayana Mengabdi (PUM) Universitas Udayana perlu dilakukan secara berkesinambungan karena memberikan manfaat yang nyata bagi masyarakat.

\section{UCAPAN TERIMAKASIH}

Penulis mengucapkan terimakasih kepada Universitas Udayana atas dana hibah Program Udayana Mengabdi tahun 2019, dan kepada tim pelaksana Program Udayana Mengabdi, atas bantuan dan kerjasamanya dalam memberikan materi dan praktek dilapangan sehingga peserta memiliki ide-ide kreatif atau strategi dalam memasarkan produk olahan yang dihasilkan. Demikian juga kepada masyarakat Desa Semaon Kecamatan Payangan Kabupaten Gianyar, atas partisipasinya, kami mengucapkan terimakasih

\section{DAFTAR PUSTAKA}

Abustam, Effendi.2005. Agroindustri Chicken Nugget. Pelatihan Penerapan HACCP pada Industri Pangan Hewani. Universitas Hasanuddin,Makassar.

Budaarsa K. 2012. Babi Guling Bali, dari Beternak, Kuliner Hingga Sesaji. Penerbit Buku Arti, (Arti Foundation), bantuan Program Widya Pataka, Badan Perpustakaan dan Arsip Propinsi Bali

Gumbira-Sa'id dan A. Harizt Intan. 2001. Manajemen Agribisnis. Ghalia Indonesia. Jakarta.

Sumardani, N. L. G., T. I. Putri, K. Budaarsa, A. W. Puger. 2019. Penganekaragaman Produk Olahan Daging Babi untuk Meningkatkan Ekonomi Masyarakat di Desa Semaon Kecamatan Payangan Kabupaten Gianyar. JUM Vol. 18 (1), Januari 2019, pp: 129-132 